\title{
TOURISM INDUSTRY OF THAILAND: THROUGH CRISIS, LOCKDOWN AND SANDBOX - TO SELF-SUFFICIENCY
}

\author{
Denis Ushakov \\ Suan Sunandha Rajabhat University, Bangkok, Thailand
}

The article analyzes the structural-functional crisis of Thailand's tourism sector caused by the 2020 pandemic. Prospects and destimulating factors of the crisis within the tourism sector for the whole socioeconomic system of the country have been assessed from the standpoint of the author's own vision of “accumulating uselessness". The author also analyzed the major consequences and development results inside the sectors of tourism and hospitality in Thailand and also - how these sectors have been reacting to economic, social and medical shocks from the coronavirus pandemic. Reformatting prospects of Thailand's tourism sector are evaluated taking into account the significant transformation of its strategic priorities, resources and market orientation.

Keywords: lockdown, tourism industry, hospitality, pandemic, accumulating uselessness, self-sufficient economy, Thailand

\section{Discomforting stats}

The problems faced by international tourism during 2020 have obviously become a global challenge for the whole sector as such as well as for multiple related businesses and sectors - from construction and agriculture to finance and telecommunications.

Abrupt closure of borders, millions of tourists stuck at the airports and resorts, cancelled flights and tours - all this has become a real seizure for the tourism industry, luckily though, it never came to be death throes. Since this situation lasted for a larger part of the whole year, it - quite predictably - has found its manifestation in the most disastrous statistical data in over two centuries of the world mass tourism development.

The $65 \%$ drop in the tourist inflows (and in absolute terms this would be around 1 bln people!) all over the world has clearly demonstrated strong dependence of international tourism on Asian countries (where the drop was much deeper, around 72\%) and also Europe (the drop of 66\%) (UNWTO, 2021).

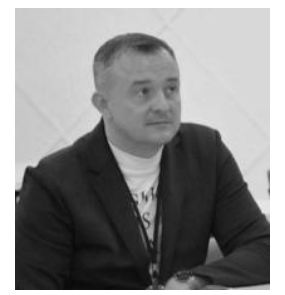

\section{Denis Ushakov}

Dr. of economy, Associate Professor, College of Hospitality Industry Management,

Suan Sunandha Rajabhat University, Bangkok, Thailand.

Research interests: tourism industry, multinational business, international service markets, migration.

E-mail: denis.se@ @sru.ac.th 
Jobs losses in the amount of 120 mln basically mean that the world tourism has rolled back in its development to the state in which it was 30 years ago (tourism used to be on this employment rate in the early 1990s).

Despite the economic rule and the social value of tourism in basically any tourist destination of 2020, majority of the countries all over the world demonstrated grim determination and readiness to "cancel tourism" momentarily, thus sacrificing it for the sake of national safety and population health.

One year since the borders' full closure and curtailing of the airline passenger service between the countries - and the world still does not have a unified approach or vision on how the crisis needs to be overcome.

Some countries (Argentine, Brazil, Viet Nam, China, India) choose to be still isolated from the external world (meaning, from tourists and migrants). Others switched to the model of the so-called "travel bubble": opening certain smaller territories and areas for tourists (Bali in Indonesia, Phuket in Thailand).

Third group of countries introduced a system for parallel regulation over incoming foreign tourists and the local population (Russia, Turkey, Mexico).

The fourth group of countries introduced mandatory quarantine in dedicated hotels and healthcare institutions for all incoming foreigners (continental Thailand).

The fifth group of countries has only express testing for all incoming tourists, provided however that only tourists from relatively safer countries may enter (UAE, Greece, Cyprus).

In the sixth group of countries limitation measures are absent as such or are just a formality (Tanzania, Armenia).

Finally, in the seventh group of countries crossing the state border would only become possible when the traveller has the so-called "vaccine passport" (some of the EU countries and Switzerland).

\section{Institutional context}

At the same time, we need to outline a range of institutional consequences from the rapid fall in the international tourism numbers.

First and foremost, we need to recall one of the most popular theories back in the 1980s - the tourism multiplier effect. In estimations of various authors, it was either 3, or 4, sometimes even higher (see, for example, Archer, 1976, 1971; Archer \& Fletcher, 1990; Coccossis \& Nijkamp, 1995; Fletcher, 1989; Hughes, 1994; Khan et al., 1995; Liu et al, 1984; Rusu, 2011; Var \& Quayson, 1985).

Differences in these calculations can be explained by unequal conditions, differences in the development level, quality of cross-sectoral connections and so on. In fact, this tourism multiplier effect seemed to be working in one direction only, while under conditions of the tourism sector stagnation this multiplier has turned into miniplier: the deeper was the fall in tourism development indicators - the less significant became the destimulating economic impacts of the tourism sector on the rest of the economy.

In our earlier research study (Ushakov, n/p) we have classified 29 countries into eight groups, depending on the rates of profit losses in their tourist sectors during 2020. According to that classification, Australia was the only country in the group with 45-49\% profit losses in tourism. Mexico, Austria and Germany formed the second group, the one with 60-64\% 


\section{TOURISM INDUSTRY OF THAILAND:}

losses. Poland, Tunisia, Thailand and Malaysia formed the third group - with $80-84 \%$ of losses, and so on.

Also, in the same study we have detected that some sort of a stimulating effect on a national economy from the tourist sector has been observed in those countries where tourism, during 2020, dropped by $70 \%$. After this "threshold" we can already observe a reverse effect: countries with more dramatic profit losses in tourism tend to have less losses in the national economy overall. This confirms that the damaging impact from tourism destimulators is somewhat limited (however, the positive impact would be same limited, primarily due to the law of diminishing utility).

In other words, the law of diminishing utility has the reverse logic and manifestations in itself. More specifically, we can talk about the accumulated uselessness, due to which the capacity of a certain economic phenomenon (in our particular case this would be the functioning tourism industry) to destabilize the whole system of economic relations under crisis would fall, once an extremum point is reached. Economic systems of the states critically dependent on tourism have clearly demonstrated the capacity to reform themselves once they reached the minimum levels back in 2020 and then to rebuild brand new production \& distribution chains.

To other factors of accumulated uselessness of the tourism industry also belong:

- abruptly dropped import volumes caused by reduction in tourism activities. Cuts in import helped to minimize the losses from the lack of foreign guests;

- reduction in the volumes of repatriated income in the sector (this is especially relevant in the case of Chinese tourists);

- lower rates of labor immigration since many newer labor migrants were traditionally looking for jobs in tourism and hospitality due to relatively lower entry barriers at their labor markets;

- decreasing number of foreign owners among the tourist industry objects, restaurants, hotels, etc. Decreasing number of foreign investors working in a country since the latter quickly came in disagreements with the tax, labor, financial, healthcare and environmental plans of the local authorities;

- growth in outbound tourism, often accompanied by an active popularization campaign of a specific destination. In many cases this growth became possible due to growing welfare of the local population and formation of a stable demand for foreign travels.

\section{Diminishing utility}

Thailand is probably the best example of a country in which international tourism has demonstrated both - diminishing utility and accumulated uselessness. Until the end of 2019, this country was an obvious global leader in tourism. In Asia, Thailand was ranked the second (straight after China) by the number of foreign arrivals per year. 2019 was the record year for the country, with over 39.5 mln tourists visiting it (Global Outlook, 2020).

At the same time, the diminishing utility of such an impressive growth in the number of international arrivals manifested itself in Thailand through lowering of the profitability rate in the tourism sector and capital outflow (primarily to the countries of tourists' origins) as well as imports growth (mainly in the most critical categories - foodstuffs, alcohol, tobacco, textile - that is, the categories actively represented in the Kingdom itself (BOT and SCB 
EIC, 2021). Another manifestation of the diminishing utility has been growing outbound tourism: back in 2019 over 9 mln Thais travelled abroad, thus leaving over 10 bln USD outside their homeland (BOT and Krungsri Research, 2021).

Additional effect from the diminishing utility in the tourism sector is the growing number of foreigners employed in tourism (in many cases in direct violation of Thailand's legislation) and the growing share of foreign property shares in tourism and hospitality (again, with some manipulations of the local legislation).

Thailand authorities have produced some initiatives aimed at reformatting of the inbound tourism in favor of new provinces and less popular islands, at development of more high-quality (and thus more expensive) tourist service at the already popular resort locations, repositioning of Thailand at the world tourism market overall, formation of tourism logistic clusters and so on. However, all these initiatives, attempts and efforts fell flat due to corruption and the temptation to earn "easy money" on the millions of tourists that were coming anyway.

The diminishing utility of Thailand's inbound tourism hit the bottom when the rapid growth in backpackers' numbers has caused the growth in local criminal rates. Thailand quickly acquired the image of a country where criminals (cyber criminals including) may easily find a safe place for themselves.

Along with India and some countries on the African continent and in Latin America, Thailand got caught up in multiple world networks of human traffickers, drug and weapon dealers, etc. This, naturally, has led to growing dissatisfaction among the local population, and this dissatisfaction was not limited to social networks only. Then Thailand witnessed a range of street protests against foreign guides and tour agents, international real estate developers and even against sex workers.

However, March 2020 quickly ended this public discussion concerning what's better for the country - endless degradation or degradation to the very end. The national borders became closed for both tourists and labor migrants. "Snowbirds" stuck on islands and famous continental resorts were rescued by the planes sent by the governments back in their countries of origin. Many workers, both Thais and foreigners, were soon forced to follow them and leave famous resort areas too, even though at the early stages of the pandemic many simply did not believe that the government would shut down the whole tourism sector and the country as such.

\section{Stages in accepting the inevitable}

During the year 2020 the Thais have passed all the classical stages in accepting the inevitable. The shock in March turned into denial by April and also into a naive belief that the quarantine won't last more than two weeks. In August, when all the hopes for a traditional summer season collapsed, the nation moved to the stage of aggression (students' protests in Bangkok and Chiang Mai) and bargaining (many businesses were demanding compensation). The stage of depression did not last that long since in December already Thailand witnessed the second wave of coronavirus which made Thais believe in the necessity to accept the bitter truth.

Thailand's government had highly ambitious plans for 2020: average monthly salary in tourism was expected to reach 650 USD; passenger inflow in Bangkok was expected to reach $100 \mathrm{mln}$ people; the shares of medical and elite tourism were expected to expand up to $25 \%$. 


\section{TOURISM INDUSTRY OF THAILAND:}

Overall, the country was ready to receive $45 \mathrm{mln}$ of international visitors (National News Bureau of Thailand, 2019). All these ambitious plans and dreams were literally trashed. The real-life end results of 2020 for Thailand were as follows (World Bank):

- profitability in the tourism sector went down by $67 \%$;

- national economic growth overall dropped by $6.4 \%$ (more than in any other ASEAN member);

- unemployment numbers went up from $0.5 \mathrm{mln}$ to almost $6 \mathrm{mln}$ people (that is, over $16 \%$ of the working age population);

- the number of Thais living on less than 10 US dollars a day (the poverty threshold) grew up to $8 \mathrm{mln}$ people;

- $\quad$ exports fell by $16 \%$, while imports fell by $13 \%$.

\section{Accumulated uselessness}

At the same time, we need to note that drastic reduction of profitability in the tourism sector did not cause either economic, or social collapse. This can be explained by the parallel influence of two factors at the same time - the accumulated uselessness of tourism under crisis and the specificity of Thais' social life as such:

- billions of losses in tourism were actually shared with multiple foreign investors (the co-owners of the largest hotels and resorts, entertainment centers, restaurants, etc.) and also with developers and private property owners;

- many tourist objects were quickly bought out by the Thais (in some cases even by public authorities) from the previous foreign owners for the price as low as $15-30 \%$ of the actual market value (this was especially the case with the most southern islands, abandoned for months);

- Thais themselves were locked up in the country for a whole year, thus, huge amounts of cash did not leave the country;

- the ban on labor migrants' entry freed up millions of jobs, in the construction sector and agriculture in the first place. This provided additional opportunities for solving the issues of unemployment caused by the lack of foreign guests and mass job cuts in the hotels, restaurants and tour agencies;

- the growth of export prices for many foodstuffs categories during 2020 has been rather favorable for many farmers. Life in rural localities, as compared to that in empty resorts, turned out to be not that dull and hopeless after all.

\section{New reality}

Thai tourism sector compressed to become internal, while prior to 2020 the share of internal tourism in Thailand was below 30\% of all travels and hotel stays and also around $22 \%$ of all profits from the tourism sector. Internal tourist flows got transformed as well. For example, one of the most important factors today is proximity of resorts to large cities, the capital in the first place, but also to large industrial and agricultural agglomerations on the North East of the country (Nakhon Ratchasima, Khon Kaen, Udon Thani).

This factor has seriously increased the survival chances of many tourist places in Pattaya and Hua Hin, and also those of islands in the Eastern part of the country (Samet, Chang). At the same time, this trend left the most southern islands completely hopeless: 
previously, these resorts used to be strongly oriented on foreign visitors and even had a nearly autonomous passenger \& logistics system of their own (international airports located directly on these islands allowed them to reduce the dependence on the passenger flows from/to the capital). Now Phuket, Krabi, Samui and other famous tourist destinations became real ghost islands, and even local population chose to abandon them.

At the same time, hotels and resorts of the Kanchanaburi, Chiang Rai, Saraburi and Nakhon Nayok, previously hardly known to mass international tourism, in 2020 enjoyed unusually high load and increased profits, much higher than the classical luxury hotels located at the globally famous tourist destinations.

Seasonality of tourism has also changed. Now the peak time falls on the weekend and public holidays in Thailand (and the government has actually introduced additional ones in order to help local resorts to survive). Traditional division into low and high seasons depending on the natural conditions became of secondary importance since competition with tourist destinations in other ASEAN countries and also in Europe practically disappeared.

Closure of borders has forced Thailand's government authorities to take measures in order to support internal tourism. From the consumer side, this included: various cashbacks for tourism-related purchases (for example, $50 \%$ of the hotel room cost is reimbursed); internal tourist charter flights with heavily discounted prices; tax deductions on personal income tax in the amount spent on internal travels with tourist purposes.

Measures taken to support the local hospitality sector include: guarantees of minimal wage for all hotel workers during the time period when their province is officially under full lockdown; tax breaks; career trainings for hotel employees so that you could return back to rural areas and find job there; engaging hotel employees in newer investment projects launched by the government (construction works in the first place). All these measures taken together have indeed revived Thailand's tourist market and helped it reach a certain balance between supply and demand, on the historically minimal level however.

Despite all the bankruptcies that took place among hotels, thus reducing the hotel offer (first of all, in the low- and mid-income segments), the supply is still significantly higher than the current level of tourist demand. This forces many hotel owners and managers to take alternative and unusual measures:

- in terms of pricing: premium pricing remains at the 2019 level only for the weekend offers, while during the working days the prices for hotel rooms of the premium category are $30-45 \%$ of the 2019 prices;

- the traditional range of hotel products and services has been seriously expanded by means of including new additional services - spa, extra meals, room category upgrade, club privileges, credit points for using additional services in a hotel (the latter, in some cases, can actually cover the cost of a hotel stay as such);

- introducing brand new offers (daycation and staycation programs as alternatives to quarantine; the so-called "luxury isolation"; work-from-hotel offers; and even annual passes (!) to all hotel services);

- emphasis on cost effectiveness (lower spending on hotel facilities and staff; postponing renovation and repairs; switching from outsourcing to internal resources only).

In a longer term, overall drop in prices and "creative" (for which read "desperate") measures taken by hotel administrators have led to lower quality of the hotel servicing: the hotels have been forced to save on all the categories of their spending, while the premium 


\section{TOURISM INDUSTRY OF THAILAND:}

rooms were occupied with the customers who were not ready to pay for additional services during their stay. Prior to the pandemic, over $80 \%$ of all hotel profits came from these additional services (Andreeva \& Ushakov, 2016), now, even the hotels of the most famous brands do not get much, apart from the hotel stay itself.

During 2020 even the language skills of hotel employees became of secondary importance. Hotel staff did not have a chance to practice their English at all, and hotel managers were swiftly reorienting on Thais consumers of various income categories. For now, the prospects of borders opening remain to be rather clouded.

\section{Scraping the barrel to survive}

In any case, we shouldn't see the pandemic tourism as a bullet in the brain of Thai tourism sector. It was more like a gradual and thorough cleanup - those who failed to reformat their activities had to withdraw from the market by the early 2021.

Foreigners searching for the ways to earn "easy money" in Thailand; political pressure by the countries millions of tourists to Thailand (first these were China, Korea and the EU only, then also India, Iran, the Middle East countries and even neighboring Malaysia); lowering competitiveness of Thai tourist offering (due to moral depreciation, loss of the exotic touch, lowering quality of services overall accompanied by growing prices at the same time, cost of baht at foreign exchange); inability to catch up with the quickly developing and modernizing neighbors (Cambodia, Viet Nam, Indonesia); failure in moving tourism activities from the extensive stage to a higher, intensive stage of development - all these and other problems in 2020 became simply memories.

This is not the first time in the history of Thailand when a certain economic sector collapsed with deplorable consequences for the related industries. Similar things happened to Thailand's financial and construction sectors back in the 1990s: they were aggressively growing, then shaped a bubble which eventually burst. Very similar was also the story of the 1997 Asian crisis which encompassed the world twice in two years, damaging dozens of large economies, including those of Japan, Russia, Turkey, Brazil and Argentina. Since those times Thailand has been super cautious with everything that concerns global finance, even when it meant sacrificing own investment attractiveness and higher places in the world economic freedom rankings.

2020 collapse of the world tourism gave Thailand an excellent opportunity to recreate the new/reformatted tourism industry. Now it is strongly oriented on the internal consumer and is clearly less ambitious when it comes to the number of visitors. It is also more selective in what concerns international arrivals. Finally, financial, investment and legal provision of tourist activities inside the country clearly became much more thorough and profound.

This "new tourism" should not become the destabilizing factor for Thailand's economy. It should not distort the economic system in favor of the services sector only, thus damaging the already traditional (and globally competitive) agriculture and industries. Last but not least, "new tourism" should not cause social tensions or provoke capital outflow to foreign accounts. The reformatted tourism industry now comes in as a supplementary element to the already well developed agriculture and industries, all three being strongly oriented on internal consumption. 
The following preconditions have been provided for Thai tourism reformatting:

- strict limitations on foreign ownership of real estate objects located in resort areas and/or related to tourism and hospitality businesses;

- prioritized reorientation on the internal consumer: introduction of discriminatory pricing, quotes for Thai tourists in hotel, tax and other financial stimuli to promote more active travel around the country, diversification of the tours offer, active development and improvement of the railway transportation, popularization of healthcare, retreat, environmental and youth tourism in the country;

- more active promotion of a relatively new type of tourism (already popular in other parts of the world) — secluded tourism (on yachts, private islands and villas). Secluded tourism is promoted with the emphasis on safety, security, social distancing and health benefits. Healthcare and rehab tourism are also promoted more actively nowadays;

- stricter limits and regulation over the employment of foreigners in tourism and hospitality (including C-level and other top positions);

- discounts, preferences and other benefits for Thai businesses directly involved in renovation of Thai tourism objects and tourist centers. Many illegally built objects in popular tourist areas have been demolished by now, and in the future there will be less chances for corruption acts in this area. Introduction of new environmental programs and projects;

- development of alternative employment opportunities for higher generation of regional income in tourist areas. For example: a new logistics center for Ranong-Chumpon, finalizing the construction of a railroad to Phuket and of a automobile road to Samui. These and other, similar projects would promote the development of agriculture and fisheries on the island and thus make them less dependent on tourism. Also, this would contribute to development of innovative tourist-medical clusters on the North of the country.

- legalizing the "localization level" within the exported tourist product. Introducing a mandatory share of expenses Thai tourist businesses need to spend on the commodities of Thai, local origin (instead of imported ones). This sort of import substitution is expected to be especially influential in the premium segment of tourist businesses;

- prevention measures taken to fight the creation and development of bubbles, primarily — on the market of resort property. For this, again, stricter disciplinary measures were taken against many foreign owners of Thai real estate objects (controlling debts on public utility bills and also tax payments).

\section{Instead of concluding remarks}

Despite the seemingly tragic nature of the situation in today's world tourism, Thailand seems to be surviving relatively well, despite all the medical consequences of the pandemic and the fact that the borders are still closed. Above we have already compared the current situation to the Asian crisis of 1997, however, actual consequences of the 2020 pandemic are hardly comparable with those of the Asian crisis, neither by strength, nor by scope. Back in 1997, the crisis affected every single Thai family and every single business in the country, without any exceptions.

In 2020 Thailand's economy indeed dropped by $6.4 \%$, and this is much higher than the similar indicators in Russia or Indonesia. Thai economic indicators of 2020 look especially unfavorable against the background of China and Viet Nam (both economies somehow managed to finish 2020 with some growth). However, we need to keep in mind that 


\section{TOURISM INDUSTRY OF THAILAND:}

comparing Thailand to China or Viet Nam is not exactly appropriate since both these economies used to be growing much more dynamically (as compared to Thailand) during the pre-pandemic years. To compare: Thailand was growing at the rate of 2-3\%, while China had $7 \%$, and in Vietnam the economic growth was then measured in two-digit numbers.

If we really need to compare material wellbeing and economic growth rates, back in 2019 Thailand was most closest to Malaysia, and also some countries of the Eastern Europe and Latin America (rather than its ASEAN neighbours). And economies of all these countries during 2020 suffered much more severely than the Thai one (see Table 1).

Table 1 - GDP dynamics in the selected countries of the world (as of 2020, Source: World Bank data)

\begin{tabular}{|l|c|c|c|}
\hline \multicolumn{1}{|c|}{ selected countries } & $\begin{array}{c}\text { GDP drop in } \\
2020 \\
\text { (in \% to 2019) }\end{array}$ & $\begin{array}{c}\text { GDP per capita as } \\
\text { of 2019 } \\
\text { (nominal) }\end{array}$ & $\begin{array}{c}\text { Dynamics of GDP } \\
\text { growth in 2019 } \\
\text { (in \% to 2018) }\end{array}$ \\
\hline Russian Federation & $-2,77$ & 11327 & 1,3 \\
\hline Indonesia & $-3,1$ & 3871 & 5,6 \\
\hline Azerbaijan & $-4,5$ & 4569 & 2,2 \\
\hline Thailand & $\mathbf{- 6 , 3 2}$ & $\mathbf{7 1 8 7}$ & $\mathbf{2 , 4}$ \\
\hline Malaysia & $-6,8$ & 10942 & 2,3 \\
\hline Croatia & $-7,9$ & 14816 & 2,9 \\
\hline South Africa & $-8,13$ & 6377 & 0,2 \\
\hline Morocco- & $-8,24$ & 3359 & 2,5 \\
\hline Bulgaria & $-8,5$ & 9267 & 3,7 \\
\hline Mexico & $-9,2$ & 9807 & $-0,1$ \\
\hline Tunisia & $-9,55$ & 3423 & 1 \\
\hline Turkey & $-9,9$ & 9346 & 0,9 \\
\hline Romania & $-11,2$ & 12120 & 4,2 \\
\hline Brazil & $-11,4$ & 8968 & 1,1 \\
\hline Argentina & -12 & 11627 & $-2,1$ \\
\hline
\end{tabular}

On the other hand, in 2020 already Thailand's government recovered from all the shock relatively quickly and switched to the traditional Asian pragmatism. The government somehow managed to prevent significant fluctuations on the financial market, thus also preventing multiple bankruptcies then threatening large businesses (including banks). Also, the government got itself directly engaged in employing thousands of newly unemployed and their relocation to agrarian regions of the country.

We can even go as far as stating that the government managed to prevent hunger in some remote areas, previously heavily dependent on tourism only, thus also preventing social unrest in the second half of 2020. At the same time, the 2020 reports of the Ministry for Finance demonstrate only a minor growth of both external and internal debt of the country and a really insignificant reduction of the gold and current reserves (despite the manifold growth of state expenditures during the whole year!) (BOT and Krungsri Research, 2021).

All this really helps the Thais to stay optimistic (see, for example, the growth of consumption expenditures by the end of 2020). Representatives of Thai tourism businesses 
are trying to stay optimistic as well. An additional reason to stay positive is the accelerated rate of vaccinations in the country (as of May-June 2021). Considering the current rates, it is very much probable that the major precondition for borders opening (at least $70 \%$ of the local population must be fully vaccinated) would be soon met. According to the Prime Minister's expectations, this might happen during autumn 2021 already.

High vaccination rates are also observed in the countries that used to supply large quantities of tourists to Thailand - China, Israel, EU countries, USA, Australia and Korea. By now, all these (and some other) countries already have a rather high rate of pent-up demand for vacations in Thailand.

Since July, 01, 2021 we have been also observing the realization of the so-called "Phuket Sandbox" - a trial opening of one tourist region in the country. Under this strategy, tourists from the safest (from the epidemiological standpoint) countries of the world are allowed to come, provided they have been fully vaccinated by one of the vaccines approved by the Ministry of Healthcare of Thailand (that is, all WHO approved vaccines and also Russia's Sputnik V). Tourists also need to have an express test upon arrival and then also have themselves tested twice during the 14-day stay on the island. Once all these tests come negative, tourists are allowed to travel to all other provinces of the Kingdom.

According to the Flight Radar data and also data provided by the Phuket International Airport (all as of July, 05, 2021), on average 2-5 international flights land on Phuket on a daily basis, mainly from Doha, Abu Dhabi, Dubai, Singapore, Kuala Lumpur and Tel Aviv. The daily number of tourists coming to Phuket under the Phuket Sandbox program is 250 to 400 people (Thailand Reopening, 2021). Other countries are also becoming interested in joining Phuket Sandbox, including some of the EU countries, Russia, Korea, Viet Nam, Japan and Iran.

In any case, even if this and other plans of Tourism Administration would be implemented in the most successful way possible, it will still take a while to return to that state of Thailand which is well familiar for millions of tourists, thousands of backpackers and hundreds of expats residing in the Kingdom.

Thailand's tourist sector needs to continue the reformatting process, placing emphasis on the modesty of expectations, use of local resources, smart strategic planning, rational use of resources and production factors and self-sufficiency overall. At the same time, quick borrowings from overseas, tempting opportunities of international integration and exports maximization should be well forgotten by now (Cartalucci, 2012). All in all, the people of Thailand should entrust their hopes to what has been the 50 years of wisdom and teachings of Rama IX.

\section{References:}

Andreeva, E.V. \& Ushakov, D. (2016). Regional and demographic tourists' inflows distribution as a factor of the national tourism competitiveness. Actual Problems of Economics, 183(9), 220227.

Archer, B. \& Fletcher, K. (1990). Multiplier Analysis in Tourism. Cahiers du Tourisme, Série C, 103.

Archer, B.H. (1976). The anatomy of a multiplier. Regional studies, 10, 71-77.

Archer, B.H. (1977). Tourism in the Bahamas and Bermuda: two case-studies. Bangor Occasional Papers in Economics, 10. 


\section{TOURISM INDUSTRY OF THAILAND:}

Archer, B.H. \& Owen, C.B. (1971). Towards a tourist regional multiplier. Regional studies, 5, 289294.

Bhaopichitr, K. (2021). Policy analyses from the TDRI. Bangkok Post.

BOT and Krungsri Research (2021). Available at: https://www.krungsri.com/en/research/industry/Industry-Horizon/industry-summary-outlook2021-2023.

BOT and SCB EIC (Outlook 4Q 2020) (2021). Available at: https://www2.deloitte.com/content/dam/Deloitte/th/Documents/about-deloitte/th-abouteconomic-outlook-special-edition-2020.pdf.

Cartalucci, T. (2012). Self-Sufficiency: A Local Solution to a Global Problem. Alternative Thai News Network (ATNN). October 28.

Coccossis, H. \& Nijkamp, P. (1995). Sustainable tourism development. Aldershot: Avebury.

Fletcher, J. E. (1989). Input-Output Analysis and Tourism Impact Studies. Annals of Tourism Research, 16, 514-529.

Global Outlook: Tourism in 2019 (2020). World Tourism Organization, Geneva.

Hughes, H. L. (1994). Tourism Multiplier Studies: A More Judicious Approach. Tourism Management, 15 (6), 403-406.

International Tourism and Covid-19 (2021). Available online at: https://www.unwto.org/international-tourism-and-covid-19.

Khan, H; Phang, S.Y \& Tjy, R. S. (1995). The multiplier effect: Singapore's hospitality industry. Cornell Hotel and Restaurant Administration Quarterly, 36 (1), 64-69.

Liu, J., Var T. \& Timur, A. (1984). Tourist income multipliers for Turkey. Tourism management, December, 280-287.

National News Bureau of Thailand (2019). Bangkok Post. 03.12.

Rusu, S. (2011). Tourism multiplier effect. Journal of Economics and Business Research, XVII (1), 70-76.

Thailand Reopening (2021). Available online at: https://www.tatnews.org/thailand-reopening/.

Ushakov, D., et al. (2019). The strategy of Thai medical services promotion at foreign markets and development of medical tourism. Geojournal of Tourism and Geosites, XII, 27(4), 1429.

Ushakov, D. (n/p). Low-replication and increasing uselessness as a new reality of the tourism industry economy in the context of a pandemic.

Var, T. \& Quayson J. (1985). The multiplier impact of tourism in the Okanagan. Annals of tourism research, 12, 497-514.

World Bank Database (2021). Available online at: https://data.worldbank.org/.

Paper submitted

Paper accepted for publishing

Paper published online
21 April 2021

14 June 2021

31 July 2021 